\title{
Antioxidant and relaxant activity of fractions of crude methanol extract and essential oil of Artemisia macrocephala jacquem
}

Niaz Ali ${ }^{*}$, Ismail Shah ${ }^{2 *}$, Syed Wadood Ali Shah², Ghayour Ahmed ${ }^{3}$, Mohammad Shoaib², Muhammad Junaid $^{2}$, Waqar $\mathrm{Ali}^{4}$ and Zahoor Ahmed ${ }^{5}$

\begin{abstract}
Background: The current work is an attempt to know about additional chemical profile of Artemisia macrocephala. Antioxidant activity is performed as the plant is reported to contain flavonoids, which have antioxidant activity in general. Relaxant activity of fractions of crude methanol extract is performed to know in which fraction(s) the relaxant constituents concentrate as we have already reported that its crude methanol has relaxant activity. Antispasmodic activity of essential oil is also performed as the plant is rich with essential oil.
\end{abstract}

Methods: Phytochemical profile of the plant is performed. Free radical scavenging activity was performed using 2, 2-diphenyl-1-picrylhydrazyl (DPPH). Relaxation activity tests of fractions and essential oil of Artemisia macrocephala were performed on sections of rabbits' jejunum. Calcium chloride curves were constructed to investigate the mode of action of plant extracts and its essential oil.

Results: We detected carbohydrates, flavonoids and saponins in A. macrocephala. At concentration $0.005 \mathrm{mg} / \mathrm{ml}$, free radical scavenging activity of ethyl acetate fraction was $121.5 \pm 2.02 \%$ of ascorbic acid.

$n$ - hexane fraction relaxed spontaneous activity with $\mathrm{EC}_{50} 0.74 \pm 0.04 \mathrm{mg} / \mathrm{ml}$. Essential oil relaxed spontaneous activity with $\mathrm{EC}_{50} 0.8 \pm 0.034 \mathrm{mg} / \mathrm{ml}$. Chloroform and ethylacetate fractions relaxed both spontaneous and $\mathrm{KCl}$-induced contractions suggesting its possible mode through calcium channels. Constructing calcium chloride curves, the test fractions showed a right shift in the $\mathrm{EC}_{50}$. Essential oil at concentration $0.1 \mathrm{mg} / \mathrm{ml}$ produced right shift with $\mathrm{EC}_{50}\left(\log \left[\mathrm{Ca}^{++}\right] \mathrm{M}\right)-2.08 \pm 0.08$ vs. control with $\mathrm{EC}_{50}-2.47 \pm 0.07$. The curve resembled the curves of verapamil, which caused a right shift at $0.1 \mu \mathrm{M}$, with $\mathrm{EC}_{50}-1.7 \pm 0.07 \mathrm{vs}$. control $\mathrm{EC}_{50}\left(\log \left[\mathrm{Ca}^{++}\right] \mathrm{M}\right)-2.45 \pm 0.06$.

Conclusions: Crude methanol and its fractions (ethyl acetate, chloroform and butanol) are rich sources of antioxidant constituents. The relaxing constituents following calcium channel blocking mechanisms are more concentrated in $n$-hexane, chloroform and ethyl acetate fractions that warrant isolation.

\section{Background}

Artemisia macrocephala belongs to family Asteraceae, which is of great medicinal importance. Artemisia macrocephala Jacquem (Synonym: Artemisia griffithiana Bioss) is $20-30 \mathrm{~cm}$ tall. It is called "Tarkha" in Pashto language. It is abundantly found in northern areas of Pakistan. Asteraceae contributes to $10 \%$ of flowering

\footnotetext{
*Correspondence: niazpharmacist@yahoo.com; ismailshah09@yahoo.com ${ }^{1}$ Department of Pharmacology, Institute of Basic Medical Sciences, Khyber Medical University, Peshawar, Khyber Pakhtunkhwa, Pakistan

${ }^{2}$ Department of Pharmacy, University of Malakand, Chakdara, Dir, Khyber Pakhtunkhwa, Pakistan

Full list of author information is available at the end of the article
}

plants. That is why it is regarded as the largest group of flowering plants [1]. The Asteraceae contains 1,600 genera and 25,000 accepted species which are of great importance [2]. Mainly, plants of Asteraceae are distributed in the semi-arid regions of tropics and subtropics of the world. So far, biologically active compounds like sesquiterpenes, lactones, volatile oils and terpenoidal compounds have been reported from the plants belonging to Asteraceae, which have anthelmintic, anti-parasitic, cytotoxic, and in vivo trypanocidal activities [3,4]. Most of the species of genus Artemisia are used as a food, forage, medicines, soil stabilizers, and for ornamental purposes. Artemisia is the largest genera of the family, which 
contains more than 400 accepted species that are distributed throughout the world [5]. Some species are allergenic or toxic, while some are invasive weeds [6].

Previously, reported constituents from essential oil of A. macrocephala are propionic acid, acetic acid, enanthic acid and isovaleric acid. Its oil also contains camphene, $\alpha$-pinine, $\beta$-pinine, limonene, $\mathrm{p}$-cymene, borneol, 1,8cineole, and camphor [7]. Upon preliminary phytochemical screening, A. macrocephala tested positive for the presence of flavonoids, alkaloids, terpenes and saponins as per our previous report [8].

We were interested in investigating some more groups of phytochemicals of crude methanol extract of $A$. macrocephala (Am. $\mathrm{CMeOH}$ ) to standardize it. Since the plant was reported to have antispasmodic activity, hence, the current work is a step forward attempt to know in which fractions the relaxant constituents concentrate. Antioxidant activity was also performed as the plant contains flavonoids, which have antioxidant activity in general $[9,10]$.

\section{Materials and methods Collection and authentication of plant's materials}

Fresh aerial parts of young shoots of $A$. macrocephala were collected in the month of August, 2009 from the hills near to Badwan Chowk, Dir Lower, Khyber Pakhtunkhwa, Pakistan. The plant was authenticated by plant taxonomist, Dr. Jehandar Shah, Vice Chancellor, Shaheed Benazir Bhutto University, Dir Upper, Sheringal. A voucher specimen "AM-01-2009" was submitted to the herbarium of Department of Botany, University of Malakand.

\section{Extraction}

The aerial parts of plant were subjected to shade drying at room temperature. The plant's materials were crushed and then pulverized by mean of a mechanical grinder to obtain fine powder. The fine powder $(5.5 \mathrm{~kg})$ was then macerated in commercial grade (50\%) methanol with occasional shaking for 22 days at room temperature. The materials were filtered off. The process was repeated 3 times. The filtrates were combined and evaporated under reduced pressure, using a rotary evaporator, till a darkgreenish color extract was obtained. It yielded 555 gram.

\section{Fractionation}

500 grams of crude methanol extract of $A$. macrocephala $(\mathrm{Am} . \mathrm{CMeOH})$ were suspended in distilled water $(400 \mathrm{ml})$, which was successively fractionated with $400 \mathrm{ml}$ of $n$ hexane. The process was repeated till complete fractionation. Similar procedure was followed for fractionation with chloroform, ethyl acetate, $n$-butanol till it successively gave $40 \mathrm{~g}$ of $n$-hexane fraction (Am. $n$-hex), $61.7 \mathrm{~g}$ of chloroformic fraction (Am.Cl), $39.4 \mathrm{~g}$ of ethyl acetate (Am.EtOAc), $38.8 \mathrm{~g}$ of butanol fraction $(\mathrm{Am} . \mathrm{BuOH})$ and
$40.7 \mathrm{~g}$ of residual aqueous fraction (Am. Aq). The fractions were stored in refrigerator.

\section{Drugs and chemicals}

All tests solutions were prepared in distilled water on the same day of experiments. Rabbits of either sex were housed in the animal house of University of Malakand. Ethical committee of the department of pharmacy approved the study protocols (Case approval \# E- AM-01-2009) as per "Bye Laws 2008 of the University of Malakand (Scientific procedures Issue- I)".

\section{Statistical analysis and calculations}

Microsoft Excel sheet was used to calculate means and standard deviations. Bar charts for antioxidant activity were drawn in Excel sheet. Graph pad prism was used to draw the curves for determination of $\mathrm{EC}_{50}$. The level of significance was tested at $\mathrm{P} \leq 0.05$ using students " $\mathrm{t}$ " test.

\section{Phytochemical profile and essential oil}

We have already reported that the plant contains alkaloids, flavonoids, saponins and terpenes [8]. Some more phytochemical profile was investigated for the presence of carbohydrates, anthraquinone glycosides and tannins as per reported procedures [11]. Essential oil, from fresh aerial parts, was obtained by simple steam distillation method which was subjected to GC/MS analysis.

\section{Antioxidant activity}

The antioxidant potential of crude methanol extract and its fractions was determined using DPPH free radical scavenging activity. Test samples of Am.CMeOH, Am. n-hex,

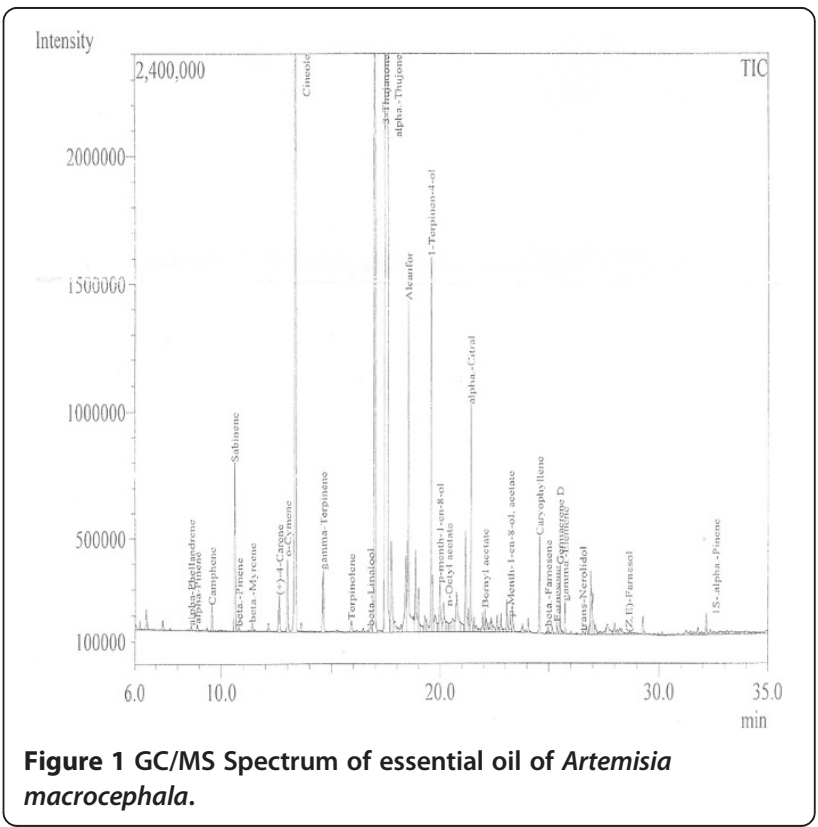


Am. Cl, Am. EtOAc, Am.BuOH and Am.Aq (2 ml each) of several concentrations $(0.5 \mathrm{mg} / \mathrm{ml}, 0.2 \mathrm{mg} / \mathrm{ml}, 0.1 \mathrm{mg} / \mathrm{ml}$, $0.05 \mathrm{mg} / \mathrm{ml}$ and $0.005 \mathrm{mg} / \mathrm{ml}$ ) were prepared. $2 \mathrm{ml}$ of DPPH (2\%) was added to all test samples. The test solutions and DPPH was prepared in methanol. Ascorbic acid was used as a standard. All the experiments were performed in triplicates. Absorbance of the sample was noted at $517 \mathrm{~nm}$ using methanol as blank [12]. Radical scavenging activity of all test samples was plotted as \% of ascorbic acid at respective concentrations.
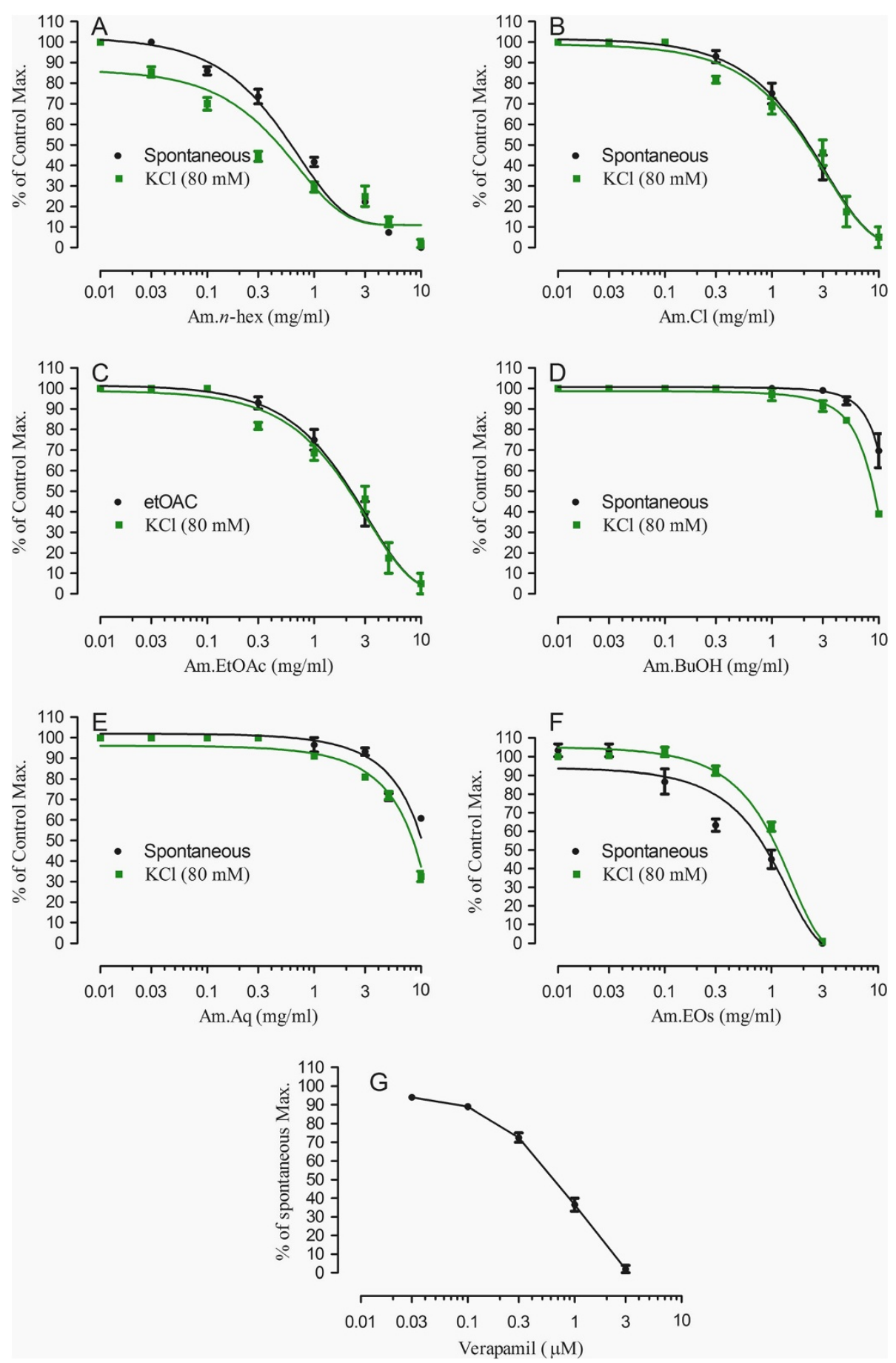

Figure 2 Effects of various fractions of Artemisia macrocephala and verapamil on spontaneous and $\mathrm{KCl}$-induced contractions in rabbits' jejunum preparations. 
Effects of various fractions on spontaneous rabbits' jejunum preparations and potassium chloride induced contractions

The antispasmodic activity of various fractions of Am. $\mathrm{CMeOH}$ was performed on spontaneous rabbits' jejunum preparations as per standard protocols [13-17]. After cervical dislocation, rabbits' abdomens were opened. About
$1.5 \mathrm{~cm}$ sections of jejunum were separated and placed in petri dishes containing Tyrode's solution. The tissues were constantly aerated with carbogen gas. These tissues were then mounted in organ bath containing Tyrode's solution. Temperature was maintained at $37 \pm 1^{\circ} \mathrm{C}$. After stabilization of the tissues for about 30 minutes, fractions of
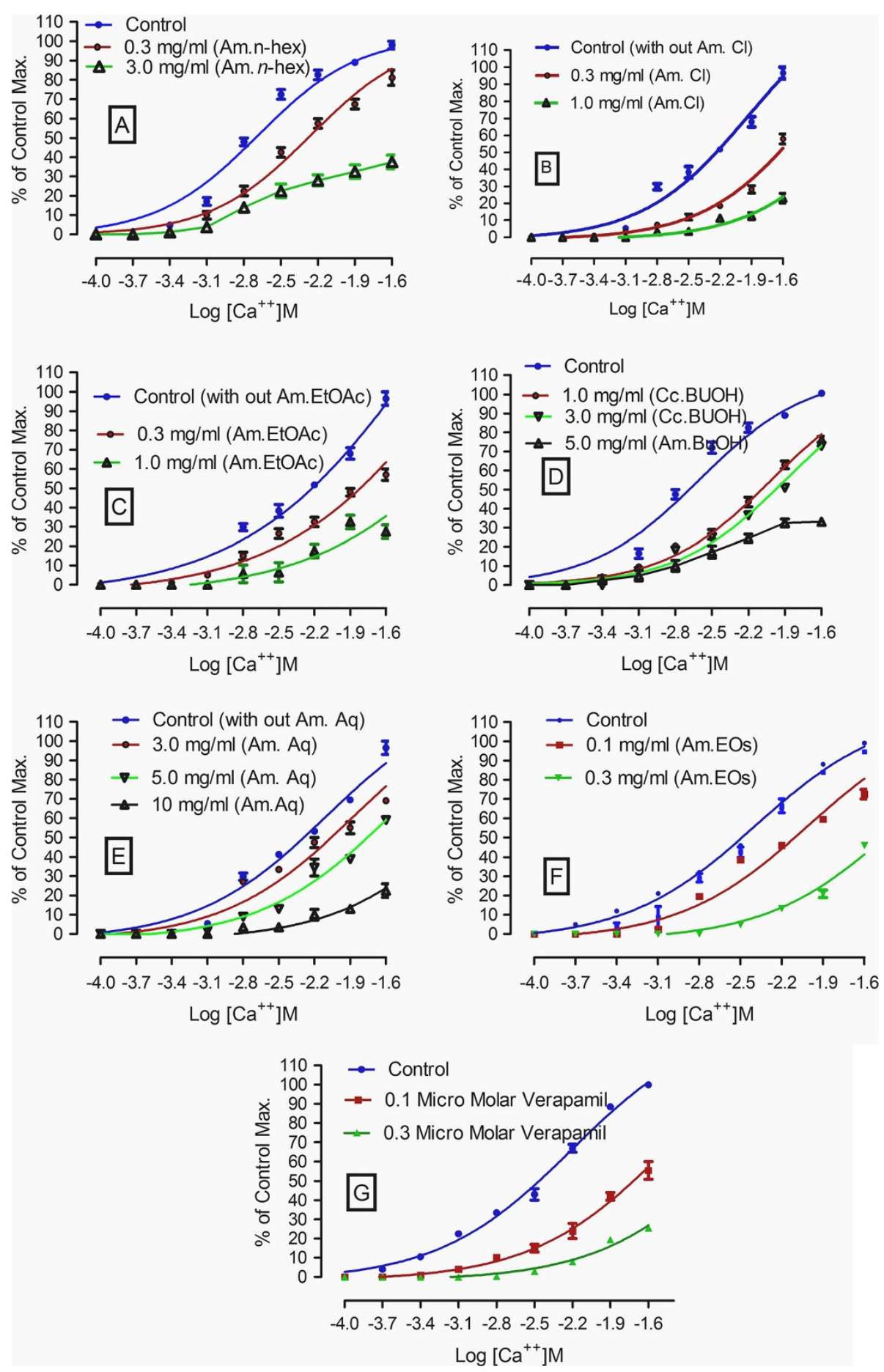

Figure 3 Effects of various fractions of methanol extract of Artemisia macrocephala and verapamil on calcium chloride curves. 
Am.CMeOH were tested in $0.01,0.03,0.1,0.3,1.0,3.0,5.0$ and $10.0 \mathrm{mg} / \mathrm{mL}$ concentrations. We also screened its essential oils for possible relaxant effects. The experiments were performed six times. For understanding of possible mechanisms of action, the test fractions were also tested on $(80 \mathrm{mM}) \mathrm{KCl}$-induced contractions in rabbits' jejunum preparations [18].

\section{Effects on voltage gated calcium channels}

Since the test fractions and essential oil relaxed high $\mathrm{KCl}-$ induced contractions, hence, we constructed calcium chloride curves as relaxing effect on $\mathrm{KCl}$-induced contractions are usually (not necessarily) following voltage gated channels. The tissues were treated with different concentrations of $A$. macrocephala in decalcifying medium. An incubation time of $1 \mathrm{hr}$ was given. Briefly describing, we exposed the tissues to calcium-free Tyrode's solution having EDTA $(0.1 \mathrm{mM})$. Then, we performed experiments in potassiumrich Tyrode's solution. Earlier, the tissues were stabilized for about 30 minutes in normal Tyrode's solution. Concentration response curves for calcium were constructed in decalcified tissues in cumulative manner at concentrations $1 \times 10^{-4}-256 \times 10^{-4} \mathrm{M}[8,14-17]$.

\section{Results and discussion}

Phytochemical analysis of A. macrocephala confirmed the presence of carbohydrates, flavonoids, alkaloids and saponins. It tested negative for proteins, tannins and glycosides. The GC/MS spectrum is presented in Figure 1. Alpha Thujone (56.24\%), 3-Thujanone (11.73\%), cineol (10.76\%), in addition to previously reported constituents, were the most prominent constituents of the essential oil of A. macrocephala. It has been also reported that flavonoids, in general, have antioxidant, cytotoxic, antitumor and antispasmodic activity $[19,20]$. Hence, it was deduced that flavonoids may be responsible for relaxant and antioxidant activities. As crude methanol extract of A. macrocephala has been reported for antispasmodic activity, hence, we currently fractionated the methanol extract to know in which fraction(s) the relaxant constituent(s) concentrate. Figure 2 describes the effects of various fractions of crude methanol extract of $A$. macrocephala on spontaneous rabbits' jejunum preparations and on potassium chloride induced contractions.
$\mathrm{EC}_{50}$ values for Am. $n$-hex are $0.74 \pm 0.04$ and $0.5 \pm 0.03$ $\mathrm{mg} / \mathrm{ml}$, respectively, for spontaneous and $\mathrm{KCl}$-induced contractions (Figure 2A). $\mathrm{EC}_{50}$ values for $\mathrm{Am} . \mathrm{Cl}$ and $\mathrm{Am}$. EtOAc on spontaneous contractions are $2.0 \pm 0.1$ and $2.3 \pm 0.1 \mathrm{mg} / \mathrm{ml}$ (Figure $2 \mathrm{~B}$ and Figure $2 \mathrm{C}$ ). $\mathrm{EC}_{50}$ values for effects on $\mathrm{KCl}$-induced contractions are $2.0 \pm 0.1$ and $2.2 \pm 0.1 \mathrm{mg} / \mathrm{ml}$ (Figure 2D and Figure 2E). While $\mathrm{EC}_{50}$ for effects of essential oil of Artemisia on spontaneous and $\mathrm{KCl}$-induced contractions are $0.8 \pm 0.3$ and $1.1 \pm$ $0.1 \mathrm{mg} / \mathrm{ml}$. Figure $2 \mathrm{G}$ describes the effects of verapamil on spontaneous rabbits' jejunum preparations with $\mathrm{EC}_{50} 0.57$ $\pm 0.04 \mu \mathrm{M}$. It is important to mention that $n$-hexane, chloroform, ethylacetate and essential oil relaxed both the spontaneous and $\mathrm{KCl}$-induced contractions up to $100 \%$. Therefore, these fractions can be sources of calcium antagonists. Calcium chloride curves (CRCs) were constructed to investigate about its possible mechanism through calcium channels or otherwise (Figure 3). Our main targets were $n$-hexane, chloroform, ethylacetate and essential oil because of their relaxing effects on spontaneous and $\mathrm{KCl}$-induced contractions. Curves were also drawn for $\mathrm{Am}$. $\mathrm{BuOH}$ and $\mathrm{Am}$. Aq fractions because of their relaxing effects at high concentrations. According to Figure $3 \mathrm{~A}, n$-hexane fraction at concentration $0.3 \mathrm{mg} / \mathrm{ml}$ produced a right shift $\mathrm{EC}_{50}-2.3 \pm 0.1 \mathrm{vs}$. control $\mathrm{EC}_{50}-2.6 \pm 0.09$. In the presence of $0.3 \mathrm{mg} / \mathrm{ml}$ of Am. EtOAc, $\mathrm{EC}_{50}$ is $-1.62 \pm 0.04$ vs. control $-2.2 \pm$ 0.2. Am. Cl at concentration $0.3 \mathrm{mg} / \mathrm{ml}$ produced a right shift with $\mathrm{EC}_{50}-1.82 \pm 0.1$. Am. $\mathrm{BuOH}$ and Am.Aq produced rightward shift at respective high concentrations i.e. 5.0 and $10 \mathrm{mg} / \mathrm{ml}$. Essential oil at concentration $0.1 \mathrm{mg} / \mathrm{ml}$ produced right shift (Figure 3F) with $\mathrm{EC}_{50}-2.08 \pm 0.08 \mathrm{vs}$. control $\mathrm{EC}_{50}-2.47 \pm 0.07$. The curves resembled the curves of verapamil which produced a right shift at $0.1 \mu \mathrm{M}$ with $\mathrm{EC}_{50}-1.7 \pm 0.07 v s$. control $-2.45 \pm 0.06$ (Figure 3G). It is the free calcium levels that are responsible for contractile effects of jejunum. The increase in cellular calcium levels is either by the release of calcium from stores in sarcoplasmic reticulum or is through the influx of calcium passing through $\mathrm{L}$ type voltage gated calcium channels into the cells [21]. Intracellular and extracellular calcium stores also exchange with one other that are responsible for the periodic depolarization and repolarization of jejunal tissues $[22,23]$. Since it is not necessary that the relaxing effects

Table 1 Results of antioxidant activity of crude methanol extract and fractions of Artemisia macrocephala

\begin{tabular}{|c|c|c|c|c|c|c|c|}
\hline \multirow{2}{*}{$\begin{array}{l}\text { Concentration } \\
(\mathrm{mg} / \mathrm{ml})\end{array}$} & \multicolumn{6}{|l|}{ Test samples } & \multirow{2}{*}{$\begin{array}{l}\text { Standard } \\
\text { Ascorbic acid }\end{array}$} \\
\hline & $\mathrm{Am} . \mathrm{CMeOH}$ & Am. $n$-hex & Am. Cl & Am. EtOAc & Am. BuOH & Am.Aq & \\
\hline 0.005 & $69.66 \pm 1.52$ & $16.83 \pm 2.84$ & $57.16 \pm 2.56$ & $75.33 \pm 2.02$ & $62.50 \pm 2.17$ & $28.33 \pm 1.75$ & $62.00 \pm 0.5$ \\
\hline 0.05 & $72.50 \pm 2.50$ & $22.66 \pm 2.51$ & $61.83 \pm 2.02$ & $79.83 \pm 2.25$ & $65.09 \pm 2.50$ & $32.16 \pm 2.56$ & $65.33 \pm 1.0$ \\
\hline 0.1 & $76.66 \pm 1.75$ & $26.33 \pm 1.25$ & $66.16 \pm 3.54$ & $82.50 \pm 2.50$ & $70.66 \pm 1.60$ & $34.66 \pm 2.02$ & $69.16 \pm 0.7$ \\
\hline 0.2 & $78.83 \pm 1.52$ & $31.50 \pm 1.50$ & $67.83 \pm 2.02$ & $85.00 \pm 2.0$ & $73.50 \pm 1.80$ & $36.66 \pm 5.20$ & $73.00 \pm 1.3$ \\
\hline$\overline{0.5}$ & $84.66 \pm 1.52$ & $38.66 \pm 1.25$ & $77.33 \pm 2.25$ & $89.50 \pm 1.80$ & $82.83 \pm 1.75$ & $42.6 \pm 2.75$ & $79.50 \pm 0.5$ \\
\hline
\end{tabular}


on $\mathrm{KCl}$-induced contraction always follow voltage gated channels, therefore, we constructed calcium chloride curves for fractions which had relaxing effects on the $\mathrm{KCl}$-induced contractions. All the fractions showed right shift in the $\mathrm{EC}_{50}$. Hence, it is suggested that these fractions are sources of relaxing constituents. The order of potency based on the right shift is: $0.1 \mathrm{mg} / \mathrm{ml} \mathrm{Am.EOs}>0.3 \mathrm{mg} / \mathrm{ml} \mathrm{Am} . n$ hex $=0.3 \mathrm{mg} / \mathrm{ml} \mathrm{Am.Cl}$. It suggested that the relaxing constituents are concentrated in these fractions that inhibited the flow of calcium through voltage gated channels [13,15]. The right shift may be attributed to the presence of phytochemicals like flavonoids and saponins as these types of

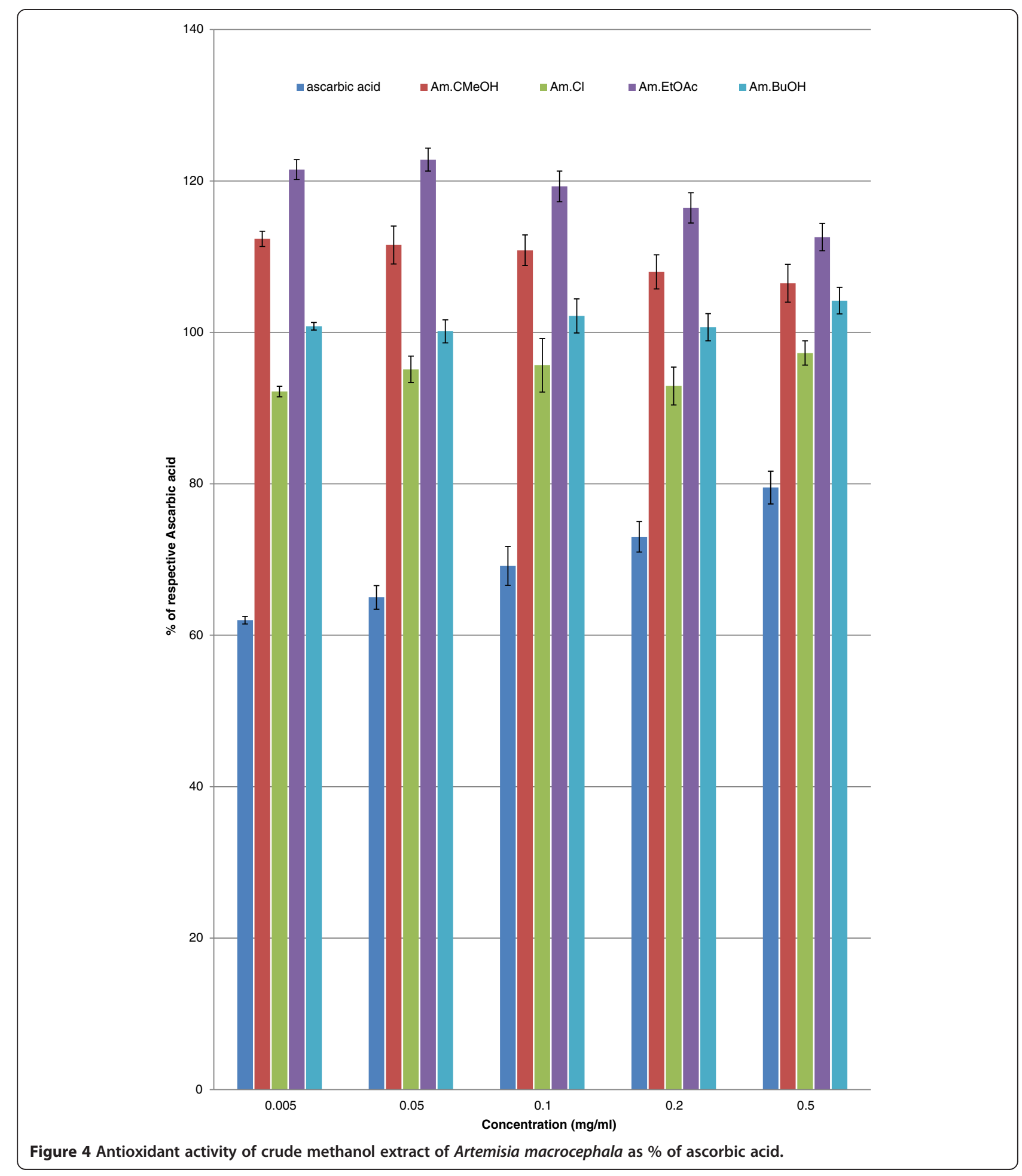


compounds, in medicinal plants, have been reported to have calcium channel blocking activity [24]. Free radicals are extremely dangerous as they are very unstable and damage the cells. Free radicals like superoxide radical (O2•-), hydroxyl radical ( $\mathrm{HO} \bullet)$, nitric oxide radical (NO•) and the lipid peroxyl radical (LOO•) damage the cells. Compounds that have lone pair of electrons can simply stabilize these free radicals and thus they are protective in nature. It has been proved that DPPH method is rapid, simple, accurate and inexpensive. It measures the ability of different compounds to act as free radical scavengers or hydrogen donors that helps to evaluate the antioxidant activity of various foods and beverages. Results of antioxidant activity are shown in Table 1. It is evident that Am.CMeOH, Am.Cl, Am.EtOAc and Am.BuOH showed excellent DPPH free radical scavenging activity. Their efficacy is comparable with ascorbic acid at respective test concentrations (Table 1). When plotted the results as \% of ascorbic acid activity (Figure 4), it is evident that the antioxidant constituents are more concentrated in ethyl acetate fraction. At $0.005 \mathrm{mg} / \mathrm{ml}$, its free radical scavenging activity is $121.5 \pm$ $2.02 \%(n=3)$ of ascorbic acid. It is evident from Table 1 that ethyl acetate, chloroform and butanol fractions are good sources of antioxidant constituents as well.

\section{Conclusions}

Crude methanol and its fractions (ethyl acetate, chloroform and butanol) are rich sources of antioxidant constituents. The relaxing constituents following calcium channel blocking mechanisms are more concentrated in $n$-hexane, chloroform and ethyl acetate fractions that warrant for its isolation.

\section{Limitations of the study}

The antioxidant activity requires further work in some other antioxidant models including superoxide, hydroxyl and nitric oxide free radicals to improve the quality of work.

\section{Abbreviations \\ (Am.CMeOH): Crude methanol extract of Artemisia macrocephala; (Am. n- hex): $n$-hexane fraction of Artemisia macrocephala; (Am. Cl): Chloroformic fraction of Artemisia macrocephala; (Am. EtOAc): Ethyl acetate fraction of Artemisia macrocephala; (Am. BuOH): Butanol fraction of Artemisia \\ macrocephala; (Am.Aq): Residual aqueous fraction of Artemisia macrocephala.}

\section{Competing interests}

The authors have no competing interests.

\section{Authors' contributions}

NA participated in collection, interpretation of data; and writing and major revision of the manuscript. IS (M. Phil Research Scholar) assisted in collection and tabulation of data. SWA assisted data collection and literature survey. GA assisted in data collection and interpretation of data. SM helped in literature survey. MJ assisted in literature survey and phytochemistry. WA assisted in literature survey. ZA helped determining the phytochemistry and secondary metabolites of the test samples. All authors read and approved the final version of the manuscript.

\section{Acknowledgements}

The authors thank Professor Dr. Jehandar Shah for identifying the plant. The authors also want to thank the Higher Education Commission, Pakistan for the grant "Pharmacological basis for ethno botanical uses of some of medicinal plants of Malakand region" for establishing of pharmacology lab at Khyber Medical University, Peshawar, where relaxant activity of the test samples was carried out.

\section{Author details}

${ }^{1}$ Department of Pharmacology, Institute of Basic Medical Sciences, Khyber Medical University, Peshawar, Khyber Pakhtunkhwa, Pakistan. ${ }^{2}$ Department of Pharmacy, University of Malakand, Chakdara, Dir, Khyber Pakhtunkhwa, Pakistan. ${ }^{3}$ Institute of Pharmaceutical Sciences, Kohat University of Science and Technology, Kohat, Khyber Pakhtunkhwa, Pakistan. ${ }^{4}$ Pharm-D Scholar, Department of Pharmacy, Abasyn University, Peshawar, KPK, Pakistan. ${ }^{5}$ Department of Biochemistry, Khyber Medical College, Peshawar, Khyber Pakhtunkhwa, Pakistan.

Received: 20 September 2012 Accepted: 2 May 2013 Published: 6 May 2013

\section{References}

1. Zareh MM: Synopsis of the Family Astereace. Int J Agri Biol 2005, 5:832-844.

2. Panero $\mathrm{JL}$, Funk VA: The value of sampling anomalous taxa in phylogenetic studies: major clades of the Asteraceae revealed. Mol Phylogenet Evol 2008, 47(2):757-782.

3. El Beyrouthy MA-AN, Labaki M, Cazier F, Najm S, AbouKaïs A: Chemical composition of the essential oil of the Artemisia arborescens I. growing wild in lebanon. LSJ 2011, 12(1):71-78.

4. Sulsen VPB, Liliana M, Virginia M, Miguel S: Antiproliferative Effect and Ultrastructural Alterations Induced by Psilostachyin on Trypanosoma cruzi. Molecules 2010, 15:545-553.

5. Willcox M: Artemisia species: From traditional medicines to modern antimalarials-and back again. J Altern Complement Med 2009, 15(2):101-109.

6. Hayat MQAM, Khan MJ, Yasmin G, Shaheen N, Shazia Jabeen S: Diversity of Foliar Trichomes and their Systematic Implications in the Genus Artemisia (Asteraceae). IJAB 2009, 11(5):542-546.

7. Dudko WBT, Usynina RV: Essential oil from Artemisia macrocephala. Chem Natur Comp 1974, 1:100-107.

8. Ali N, Shah S, Shah I: Preliminary Phytochemical Screening and Antispasmodic Activity of Artemisia macrocephala Jacquem. J Young Pharm 2011, 3(2):125-128.

9. Sparg SG, Light ME, van Staden J: Biological activities and distribution of plant saponins. J Ethnopharmacol 2004, 94(2-3):219-243.

10. Ali N, Shah SW, Shah I, Ahmed G, Ghias M, Khan I: Cytotoxic and anthelmintic potential of crude saponins isolated from Achillea Wilhelmsii C. Koch and Teucrium Stocksianum Boiss. BMC Complement Altern Med 2011, 11(1):106.

11. Aduragbenro DAA YO, Adeolu AA, Olanrewaju MJAS, Olumayokun AO, Janet MM: Blood pressure lowering effect of Adenanthera pavonina seed Extract on normotensive rats. Rec Nat Prod 2009, 3(2):82.

12. Mazimba OMR, Motlhanka D: Antioxidant and antibacterial constituents from Morus nigra. Afr J Pharma Pharmacol 2011, 6:751-745.

13. Gilani AH, Aziz N, Khurram IM, Rao ZA, Ali NK: The presence of cholinomimetic and calcium channel antagonist constituents in Piper betle Linn. Phytother Res 2000, 14(6):436-442.

14. Ali N, Ahmad B, Shah SW: Spasmogenic and spasmolytic activities of Onosma griffithii Vatke. Pak J Pharm Sci 2011, 24(4):553-558.

15. Ali N, Ahmed G, Shah SW, Shah I, Ghias M, Khan I: Acute toxicity, brine shrimp cytotoxicity and relaxant activity of fruits of callistemon citrinus curtis. BMC Complement Altern Med 2011, 11:99.

16. Ali N, Ali Shah SW: Antispasmodic activity of Teucrium stocksianum Boiss. Pak J Pharm Sci 2011, 24(2):171-174.

17. Ali N, Shah S: Spasmolytic Activity of Fruits of Tamarindus indica L. J Young Pharm 2010, 2(3):261-264.

18. Farre AJCM, Fort M, Gutierrez B: Differential effects of various Ca++ antagonists. Gen Pharmacol 1991, 22:177-181.

19. Middleton EJ CK: The impact of plant flavonoids on mammalian biology: implications for immunity, inflammation and cancer. London: Chapman and Hall; 1993. 
20. Harborne JBWC: Advances in flavonoid research since 1992. Phytochemistry 2000, 6:481-504.

21. Grasa LRE, Arruebo MP, Plaza MA, Murillo MD: The role of $\mathrm{Ca}+2$ in the contractility of rabbit small intestine in vitro. J Physiol Pharmacol 2004, 55:639-650.

22. AF B: How do drugs initiate contractions in smooth muscles. Trends Pharmacol Sci 1981, 2:261-265.

23. Abouzid S, Elshahaat A, Ali S, Choudhary MI: Antioxidant activity of wild plants collected in Beni-Sueif governorate, Upper Egypt. Drug Discov Ther 2008, 2(5):286-288

24. Revuelta MPCB, Hidalgo A: Depolarization-dependent effect of flavonoids in rat uterine smooth muscle contraction elicited by $\mathrm{CaCl}_{2}$. Gen Pharmacol 1997, 29:847-857.

doi:10.1186/1472-6882-13-96

Cite this article as: Ali et al: Antioxidant and relaxant activity of fractions of crude methanol extract and essential oil of Artemisia macrocephala jacquem. BMC Complementary and Alternative Medicine 2013 13:96.

\section{Submit your next manuscript to BioMed Central and take full advantage of:}

- Convenient online submission

- Thorough peer review

- No space constraints or color figure charges

- Immediate publication on acceptance

- Inclusion in PubMed, CAS, Scopus and Google Scholar

- Research which is freely available for redistribution 